症例

治癒手術をおこないえた異時性三重複癌の 1 例

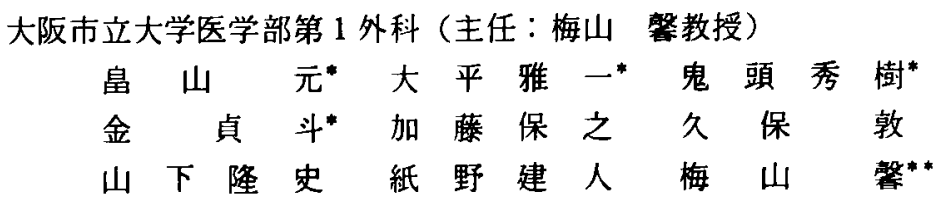

\title{
A CASE OF CURATIVELY RESECTED METACHRONOUS TRIPPLE CANCER
}

Gen HATAKEYAMA, Masaichi OHIRA, Hideki KITO, Jung-doo KIM, Yasuyuki KATO, Atsushi KUBO, Takafumi YAMASHITA, Kenjin KAMINO and Kaoru UMEYAMA

1st. Department of Surgery, Osaka City University School of Medicine (Director: Prof. Kaoru UMEYAMA)

いずれる治瘾切除をおこないえた異時性三重複癌を経験した。

患者は72歳，女性，第一癌，子宮頚癌 (non-keratinizing squamous cell carcinoma), 第二癌, 胃癌 (poorly differentiated adenocarcinoma), 第三癌, S 状結腸癌 (well differentiated adenocarcinoma).

第一癌と第二癌お上び第二癌と第三癌の間隔はともに 5 年以上であり，第一癌の子宮 䅡癌術後にコバルト照射が, 第二癌の胃癌術後に制癌剂療法（ 3 年11力月間）が行なわ れている.

近年の癌の診断, 治療の進歩にともない, 重複癌の報告は年々増加の傾向にあるが， 根治術がなしえた報告はなお少なく, 第一癌の根治術後る厳重に follow up し, 重複癌 発生の可能性を念頭におき，第二策三癌を治海切除可能な時期に発見することが必要

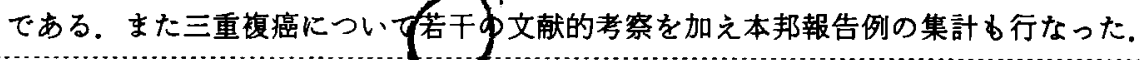

\section{緒}

重複癌症例の報告は近年の診断, 治療の進歩に上り 年々増加の傾向にあるが, 三重複癌の報告はなお少な く、なかでも治疾手術がなされた症例は極めて少ない. われわれはいずれす治度手術がなれた異時性三重 複癌の一例を経験したので，本邦における三重䙓癌に ついて若干の文献的考察を加えて報告する.

症例：72歳，女性

家族歷：妹が肺癌にて死亡

既往歴：癌以外に特記すへきき事項はない。

現病歴：〈第一癌>昭和 45 年 3 月，子宮頚癌の診断 のもとに某大学病院にて広汎子宮全摘術ならびに術後
コバルト照射を $5 け($ 線量不明)術後経過は良好であっ た.

<第二癌>昭和50年 3 月, 胸やけを主訴とし，われ われの外来を受診し，胃腸透視および内視鏡検查によ り幽門部小弯側の Borrmann 3 型胃癌と䛦断され，昭 和50年 3 月25日, 胃覀全摘術が施行された。手術所見 はPo Ho $S_{1} \quad N_{1}$ で $R_{2}$ 切除術が施行できた。術後は MMC, $5 F U$ の静脈内および,フトラフール内服による 化学療法が 3 年11カ月間行なわれた。総投与量は MMC $24 \mathrm{mg}, 5 F U ~ 3,000 \mathrm{mg}$, フトラフール $855 \mathrm{~g}$ で あった。

<第三癌>第二癌の術後怪過観察中の昭和 55 年 11 月 頃より少量の下血があり, 昭和56年 2 月注腸透視を施 行し，S 状結腸前壁に母指頭大の明瞙な周堤および線

" 臨床研笂 “* 直接指䓕者 

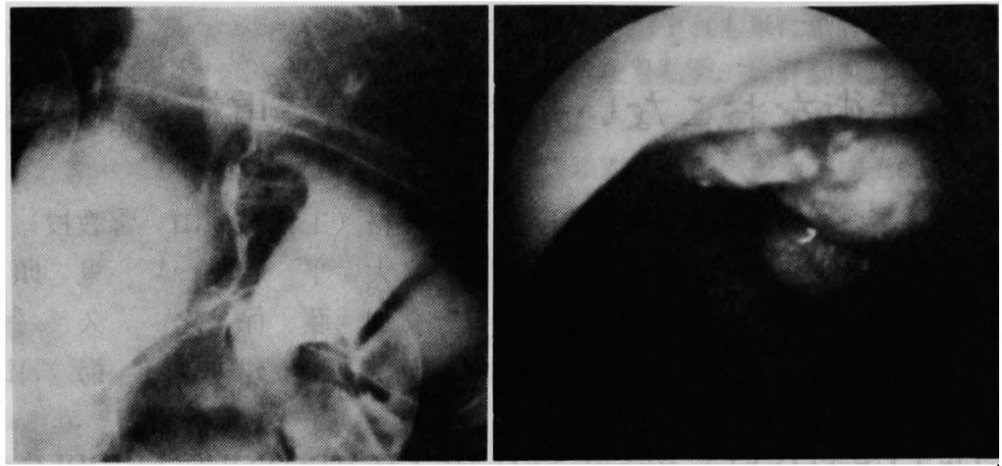

図 1

（左）注腸透視では $\mathrm{S}$ 状結腸前壁に母指頭大の明瞙な周堤および線状の謴㻛を伴ら腫 瘤陰影がみられた。

(右)ロマノスコーブにては, 肝門輪より $13 \mathrm{~cm}$ 口側の 1 時から 3 時にかけて出血を伴 う Borrann 2型様腫瘤が認められた。

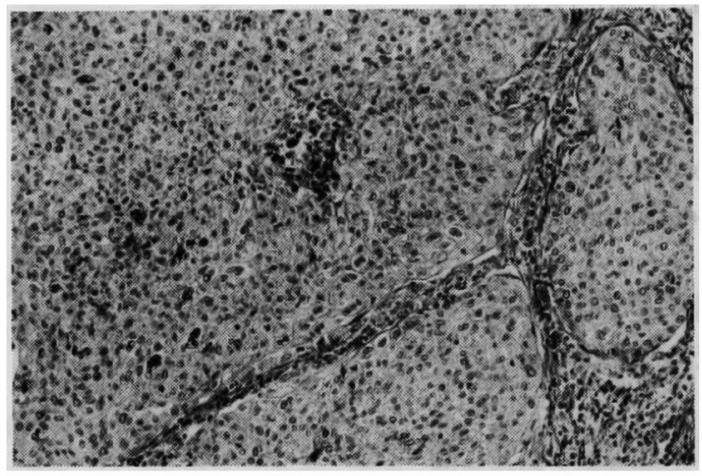

図 2

子宮頚癌の組織は，比較的低分化の non-keratizing squamous cell carcinomaであった.
状の潰瘍を伴 5腫瘤陰影がみられた(図 1 左)。ロマ) スコープでは, 肛門輪より $13 \mathrm{~cm}$ 口側の 1 時から 3 時 にかけて易出血性の Borrmann 2型様腫瘤が認められ た。生検にて，腺管腺癌が確定され，昭和56年 2 月24 日に S 状結腸切除術を施行した。手術所見はPo Ho So No $R_{1}$ 切除術であった。

切険標本书よひ組織所見：<第一癌〉子宮頚癌の组 織は，比較的低分化の non-keratinizing squamous cell carcinoma であった（図 2 ）。第二癌>胃幽門輪 前部小弯側に, $5.5 \mathrm{~cm} \times 4.5 \mathrm{~cm}$ の Borrmann 3 型の胃 癌で (図 3 左), 組織学的には䟿膜面まで浸潤した poorly differentiated adenocarcinoma（図 3 右）で,



図 3

（左）胃幽門輪前部小弯側に, $5.5 \mathrm{~cm} \times 4.5 \mathrm{~cm}$ の Borrmann 3型の胃癌をみとめ（右） 組織学的には墏膜面まで漫潤した poorly differentiated adenocarcinomaであっ た. 


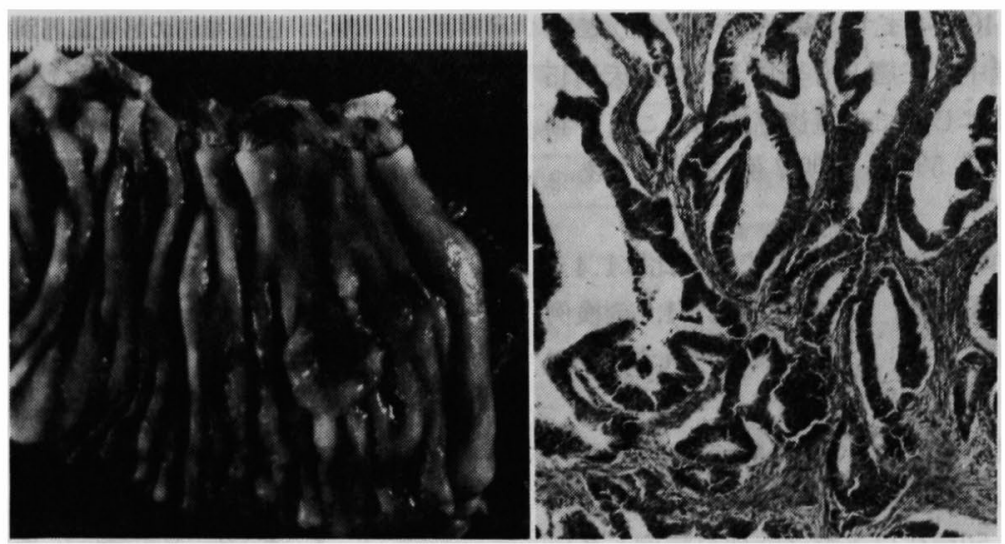

図 4

（左）S 状結腸前壁に1.7cm × 1.6cm の Borrmann 2型様 $\mathrm{S}$ 状結腸癌をみとめ（右） 組織学的には well differentiated adenocarcinoma であった。

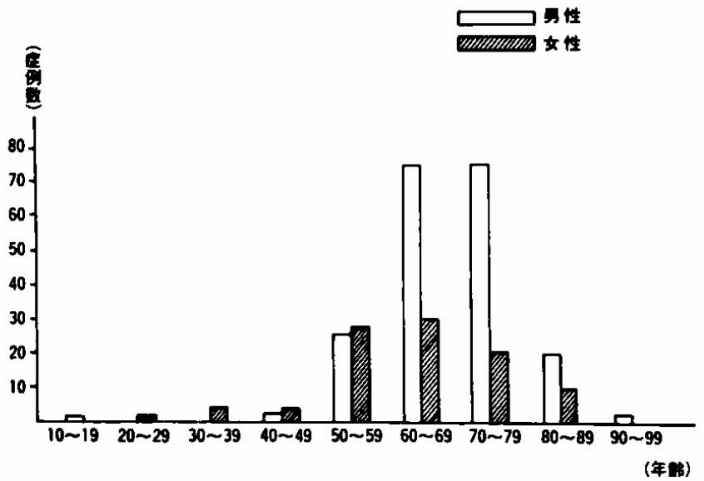

図 5 三重被癌の発生年柃，性別分布(1923 1981.2)

se, INF $\gamma$, Vo, Lyo, $n_{1}$, stage III で absolute curative resectionがなされた。第三癌〉S 状結腸壁に1.7 $\mathrm{cm} \times 1.6 \mathrm{~cm}$ の Borrmann 2 型棣 S 状結腸がみられた (図 4 左), 組織学的には well differentiated adenocarcinoma (图 4 右) で, pm, INF $\alpha$, Vo, Lyo, $n_{1}$, stage II, Dukes の stage 分類ではClass Cであり relative curative resectionがなされた。

第三癌の手術後 5FU, MMC の静脈内投与および, フトラフール内服による化学療法を行ない, 現在患者 は健在で経過観察中である。

考察

重複癌の定義で, 最も古典的なものでは, Billroth" の, (1) 重複癌を構成する腫瘍は相互に異なった組織像 を呈していること,(2) 各腫瘍は組織発生学的に母組織 と関連を有していること,(3) 各腫場はそれぞれ固有の
転移巣を有すること，といらのがあるが，今日では， この条件は呼吸器や消化器系統のような同一系統に発 生した重複癌や早期癌の症例が除外される場合が生し るため適当でないと考えられている。そこで一般には 1932年にWarren と Gatesが堤唱した，(1) 各腫瘍は 一定の悪性像を呈していること,(2) 相互に離れて存在 していること, (3) 一方が他方の転移でないこと，とい ら定義が広く用いられている。しかしながら，この定 義でも同一䁍器の多発癌, 両側癌, ポリポージスの癌 化などの位置つけけ問題が残されている。

われわれは上記の Warren と Gates の定義11に加え て赤崎 ${ }^{2}$ 之同様に, 多発性骨髄腫, 細網肉腫等の多中心 性に発生した悪性腫湯は一つの悪性腫湟と考兄，さら に同一缄器の多発癌や両側癌は一応除外した。

また悪性腫場の発生間隔については Moertel ${ }^{3) ら は ~}$ 6力月以上を経過して他の癌が発見された場合をまた 北畠4)は 1 年以上を経過した場合を異時性重複癌と定 義している.

今回の自験例では, 胃癌は子宮䅡癌治療の 5 年後, また $\mathrm{S}$ 状結腸癌は胃癌手術の 5 年11力月後といずれ む 5 年以上程過した時点で見出され，その組織像は扁 平上皮癌, 低分化腺癌, 高分化腺癌と異なった所見を 示し，それぞれ治症手術が行なわれている，したがっ て本症例は上記重複癌の定義をみたし，また， Moertel の異時性重複癌の定義をみたす異時性三重複癌とみな すことができる。

これらの重複癌の定義にしたがい, 本邦における三 重複癌の報告例は，われわれが，集計しえたかぎりで 
は自験例を含めて，1981年までに267例であった。これ らのなかで臨床経過中に三癌とも発見された臨床例45 例(16.9\%), 剖検時はじめて三重複癌であることが判 明した剖検例 215 例 $(80.5 \%)$ ，不明 7 例 $(3.0 \%)$ であっ た。

性別は, 男155例, 女108例, 不明 4 例で男女比は1.4： 1 であり臨床例では男24例, 女19例, $1.3: 1$, 剖検例 では男124例，女91例，1.4：1，と差はみられず，いず れも男性にやや多い傾向にあった。

年齢は, 最少 16 歳, 最高 90 歳で, 年龄分布は(图 5 ), 男女ともに50歳代より急激に增加し，60７0葴代に ピークが見られた。50歳代以下では女性の症例が多い 傾向にあり，熊谷”らの報告と一致していた。

平均年齢は，男68.7歳，女61.2歳で本邦二重複癌の 平均より男は約12歳，女は約10歳高龄であった。

腫湯の発生間隔は, 臨床例で異時性のものでは, 第 一癌と第二癌の間隔が平均 3.5 年, 第二癌と第三癌は平 均1.7年であった。

発生臓器は，三重複癌全体についてみるど（表 1)， 胃 (17.7\%)，肺 (9.3\%)，甲状腺 (7.5\%) などに多 く,ついで結腸, 直腸, 前立腺の順であるが,これを さらに臨床例と剖検例に分けてみると（表 2，3）臨 床例では胃 $(21.5 \%)$, 結腸 $(9.6 \%)$, 直腸 $(8.1 \%)$, 次いで食道, 乳腺, 子宮であり, 剖検例では, 胃 $(15.6 \%)$, 肺 (10.6\%), 甲状腺 $(8.0 \%)$, 次いで前立 腺, 結腸, 腎蔵の順で, 剖検において, 甲状腺, 前立

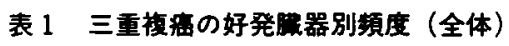

\begin{tabular}{|c|c|c|c|c|c|}
\hline & \multicolumn{3}{|c|}{ 発生滕器 } & 症例数 & (\%) \\
\hline 1 & \multicolumn{3}{|c|}{ 胃 } & 141 & $(17.7)$ \\
\hline 2 & \multicolumn{3}{|c|}{ 肺 } & 74 & $(9.3)$ \\
\hline 3 & 甲 & 状 & 腺 & 60 & $(7.5)$ \\
\hline 4 & 結 & & 腸 & 49 & ( 6.1$)$ \\
\hline 5 & 直 & & 腸 & 43 & $(5.4)$ \\
\hline 6 & & 立 & 腺 & 43 & $(5.4)$ \\
\hline 7 & 食 & & 道 & 42 & $(5.3)$ \\
\hline 8 & 焣 & & 荍 & 38 & $(4.9)$ \\
\hline 9 & 䀒 & & 腈 & 37 & $(4.8)$ \\
\hline 10 & 子 & & 宮 & 34 & $(4.3)$ \\
\hline 11 & 膀 & & 胱 & 34 & $(4.3)$ \\
\hline 12 & 秏 & & 腺 & 30 & ( 3.8$)$ \\
\hline 13 & 喉 & & 頭 & 29 & $(3.6)$ \\
\hline 14 & 胆 & & 睃 & 21 & $(2.6)$ \\
\hline \multirow[t]{3}{*}{15} & 䐙 & & 灀 & 21 & $(2.6)$ \\
\hline & そ & の & 他 & 102 & $(12.8)$ \\
\hline & \multicolumn{3}{|c|}{ 計 } & 798 & $(100)$ \\
\hline
\end{tabular}

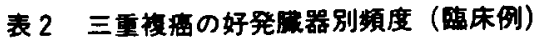

$(1955 \sim 1981.2)$

\begin{tabular}{|c|c|c|c|c|}
\hline & \multicolumn{2}{|c|}{ 発生虂器 } & 症例数 & $(\%)$ \\
\hline 1 & \multicolumn{2}{|c|}{ 胃 } & 29 & $(21.5)$ \\
\hline 2 & 結 & 腸 & 13 & $(9.6)$ \\
\hline 3 & 直 & 腸 & 11 & ( 8.1$)$ \\
\hline 4 & 食 & 道 & 9 & $(6.7)$ \\
\hline 5 & 手 & 腺 & 9 & ( 6.7$)$ \\
\hline 6 & 子 & 宮 & 8 & ( 5.9$)$ \\
\hline 7 & 哄 & 頭 & 7 & ( 5.2$)$ \\
\hline 8 & 甲 状 & 腺 & 6 & $(4.4)$ \\
\hline 9 & 膀 & 胀 & 6 & $(4.4)$ \\
\hline \multirow[t]{3}{*}{10} & \multicolumn{2}{|c|}{ 肺 } & 5 & ( 3.7 ) \\
\hline & その & 他 & 32 & (23.7) \\
\hline & 計 & & 135 & $(100)$ \\
\hline
\end{tabular}

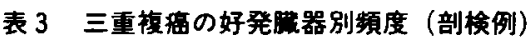

$(1923 \sim 1979)$

\begin{tabular}{|c|c|c|c|c|c|}
\hline & \multicolumn{3}{|c|}{ 発生臟器 } & 症 例 数 & $(\%)$ \\
\hline 1 & \multicolumn{3}{|c|}{ 胃 } & 101 & $(15.6)$ \\
\hline 2 & \multicolumn{3}{|c|}{ 肺 } & 69 & $(10.6)$ \\
\hline 3 & 甲 & 状 & 腺 & 52 & $(8.0)$ \\
\hline 4 & 前 & 立 & 腺 & 41 & ( 6.3$)$ \\
\hline 5 & 結 & & 腸 & 35 & ( 5.4$)$ \\
\hline 6 & 腎 & & 㳀 & 35 & $(5.4)$ \\
\hline 7 & 肝 & & 嘕 & 33 & ( 5.1$)$ \\
\hline 8 & 直 & & 腸 & 32 & ( 4.9$)$ \\
\hline 9 & 食 & & 道 & 32 & $(4.9)$ \\
\hline \multirow[t]{3}{*}{10} & 膀 & & 胱 & 29 & $(4.5)$ \\
\hline & $\xi$ & の & 他 & 189 & ( 2.9$)$ \\
\hline & \multicolumn{3}{|c|}{ 計 } & 648 & $(100)$ \\
\hline
\end{tabular}

腺の占める割合が臨床例より大いのはこれらの䟮器 の occult cancer が剖検時に見出されることが多いた めと思われる.

発生頻度は, 1970年 1979年までの10年間の病理剖 検輯報における重複癌症例の推移でみると, 全悪性戛 湯総数に対し三重複癌の占める比率は約 $0.1 \%$ て全重 複癌症例に対して3.5\% - 5.2\% (平均 $3.8 \%$ )で1974年 以降は $4 \%$ となっている。

本邦における三重複癌発生率は，0.018\% 〜0.61\%(1) といわれているが，今回のわれわれの集 計ではこれらの約 2 咅の值を示している。これは病理 剖検例で悪性腫瘍の占める比率が高い(悪性腫場は 76\%を占める。）ためと思われる。

また従来の報告例の集計はWarren と Gatesの定 義に加えて，それぞれ独自の条件が付加されており， 集計の対象例が異なっているためにそれぞれの発生革 
表 4 本邦におけろ三重複瘦の切除例（1964～1981.2）

\begin{tabular}{|c|c|c|c|c|c|c|c|}
\hline & 绑告者 & 年度 & 年令.㭌 & & 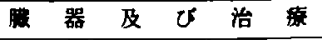 & & 期 \\
\hline 1 & 中村 ${ }^{3}$ & 1964 & 638 & 1 首 禹(胃切除) & 2 直晹禹(根治術) & 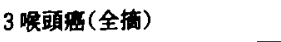 & $1 \stackrel{1 Y}{=} 2 \stackrel{10 M}{=} 3$ \\
\hline 2 & 朝合" & 1965 & $52 \quad \delta$ & 1胃 镭(胃切除) & 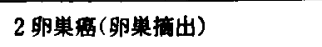 & 3 子宮顒雷(根治術) & 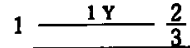 \\
\hline 3 & 坂下 (3) & 1968 & $\begin{array}{ll}56 & \delta \\
\end{array}$ & 1 上行結胆密(右半切除) & 2 直晹盘（根治珑） & 3 周啫門重(胃切除) & $1 \stackrel{2 Y}{-} 2 \stackrel{13 Y}{=} 3$ \\
\hline 4 & 佐䍣 & 1970 & $66 \%$ & 1口蓋垂癌(腫觜切除) & 2冒 演(全捕術) & 3 甲状腺 (垔全換) & $1 \stackrel{9 Y}{2} 2 \stackrel{1}{-} 3$ \\
\hline 5 & 天羽 (5) & 1971 & $\begin{array}{ll}56 & \delta \\
\end{array}$ & 1 下行結陽癌 (左半切除) & 2 胃 瘦(胃全摘) & 3 食道密(腹部食道切除) & $7 \mathrm{M}-\frac{2}{3}$ \\
\hline 6 & 三品16) & 1972 & $61 \%$ & 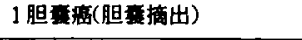 & 2 乳房ペーシェット程(乳房切断) & 3 胃 科(胃切除) & 全て異時性 \\
\hline 7 & 谷口王) & 1973 & 60 ๆ & 1右秘(根治術) & 2 胃 曋(胃切除) & 3 横行結渴穜(根治術) & $1 \longrightarrow \frac{2 Y}{-} \frac{2}{3}$ \\
\hline 8 & 神前 ${ }^{18)}$ & 1975 & 不 明 & 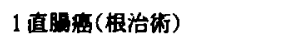 & 2 胃 渴(胃切除) & 3 上行結渴馧(右半 & $1 \stackrel{5 Y}{=} 2 \stackrel{5 Y}{=} 3$ \\
\hline 9 & 占部 ${ }^{19)}$ & 1976 & $\begin{array}{ll}30 & 9 \\
\end{array}$ & 1卵果舟(根治術) & 2 勝悓要（狫灼術） & 3胃 堛(胃切除) & $1 \stackrel{2 Y}{2} \stackrel{2 Y}{=} 3$ \\
\hline 10 & 松原 ${ }^{20}$ & 1976 & $63 \quad \delta$ & 1 盟盂癌(罱摘) & 2 勝腃密 (部分切除) & 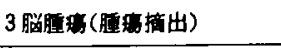 & $1 \stackrel{5 Y}{=} 2 \stackrel{1 Y}{=} 3$ \\
\hline 11 & 萁田 ${ }^{212}$ & 1977 & $\begin{array}{ll}53 & \delta \\
\end{array}$ & 1 胃 稫(全摘術) & 2 食道盘(部分切除) & 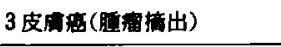 & $1-\frac{1 y}{3}$ \\
\hline 12 & 踰木22) & 1976 & $50 \lesssim$ & 1胃 癌(胃切除) & 2 結膓䖝 (右半切除) & 3 直腸芴(根治術) & $\frac{1}{2} \longrightarrow 1 y-2$ \\
\hline 13 & 荒川233 & 1978 & $\begin{array}{ll}56 & \delta\end{array}$ & 1 子宮体艒(根治術) & 2 直渴癌(前方切除) & 3 上行結間癌(右半切除) & $1 \stackrel{1 Y}{=} 2 \stackrel{1 Y}{=} 3$ \\
\hline 14 & 小田原 ${ }^{24}$ & 1978 & $\begin{array}{ll}38 & 5\end{array}$ & 1 横行結腸癌 (結腸部分切除) & 2 胃 癌(胃切除) & 3 直晹ポリーフ䗝(前方切除) & $1 \stackrel{1.6 Y}{-} 2 \stackrel{1 \mathrm{M}}{\longrightarrow} 3$ \\
\hline 15 & 佐本 25$)$ & 1979 & $48 \quad \delta$ & 1 尿管潞(雪冢管摘出) & 2 横行結腸穗（切除術） & 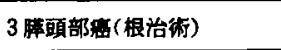 & $1 \frac{8 Y}{2} \stackrel{4 Y}{3}$ \\
\hline 16 & 僼永 ${ }^{26)}$ & 1980 & 52 ㅇ & 1 子宮頭莬(全捕術) & 2 骨細胞㾇(胃摘) & 3 甲状腺盘(垔全描) & $1-1 x$ \\
\hline 17 & 自酸 & 1981 & 72 \& & 1 子宮頊践(全捕術) & 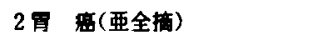 & 3 S 状結腸新(七刀除術) & $1 \stackrel{5 Y}{-} 2^{5} \stackrel{Y 11 M}{=}_{3}$ \\
\hline
\end{tabular}

の比較は困難である，今後の重複癌症例の報告につい ては, 馬場12)らが述べるよ5に，共通の定義に基ついて 集計されることが望ましいと思われる。

三重複癌臨床例43例の5ち，三癌とも切除できた 之, 報告時生存している症例は, 17例(6)113) 26)で臨床例 での切除率は $40 \%$ であった（表 4 ）また剖検例を含め た三重复癌全体に対する切除例の占める割合は $6.4 \%$ であった。

切除例の5ちわけは，男10例，女6例，不明 1 例で平 均年龄は62.7歳である。これらは，三癌とる同時に発 生したるのはなく，第一癌と第二癌のみが同時性のむ の 2 例, 第二癌之第三癌か;同時性のもの 5 例, 他は三 癌ともに異時性であった。 また切除例の腫瘍の発生間 隔の平均は，第一癌と第二癌3.9年, 第二癌之第三癌は 2.1年であった。

その発生臟器は(表 5 ), 胃 $25.5 \%$, 結腸 $17.6 \%$, 直 腸 $11.8 \%$, 子宮7.8\%で次いで膀胱, 即巣, 乳腺の順で あり, 術後の経過観察では，とくに胃，結腸，直腸を 中心とした消化器系, 泌永生殖器系の精査を行ならこ とが必要であり，女性ではこれらに加え子宮，乳腺の 精査す充分に行なわれる必要があると思われる。しか し切除例の大半を占める消化器, 子宮頚癌, 乳癌は比

\section{表 5 三重被满切除例の好発䑏器別頻度}

\begin{tabular}{|c|c|c|c|c|c|}
\hline \multicolumn{6}{|c|}{$(1964 \sim 1981.2)$} \\
\hline & \multicolumn{3}{|c|}{ 発生脿器 } & 应例数 & (\$) \\
\hline 1 & \multicolumn{3}{|c|}{ 胃 } & 13 & $(25.5)$ \\
\hline 2 & 結 & & 腸 & 9 & $(17.6)$ \\
\hline 3 & 直 & & 腸 & 6 & $(11.8)$ \\
\hline 4 & 子 & & 宮 & 4 & $(7.8)$ \\
\hline 5 & 膀 & & 脱 & 2 & $(3.9)$ \\
\hline 6 & 卵 & & 果 & 2 & ( 3.9$)$ \\
\hline 7 & 乵 & & 腺 & 2 & $(3.9)$ \\
\hline 8 & 甲 & 状 & 腺 & 2 & $(3.9)$ \\
\hline 9 & 食 & & 道 & 2 & $(3.9)$ \\
\hline \multirow[t]{3}{*}{10} & 盟 & & 路 & 2 & $(3.9)$ \\
\hline & $\xi$ & の & 他 & 7 & $(13.9)$ \\
\hline & & 計 & & 51 & $(100)$ \\
\hline
\end{tabular}

較的発見頻度の高い癌であるが，剖検例で胃癌に次い で多い肺癌の切除例は 1 例すなく，今後肺癌とともに occult cancerの多い前立腺癌や甲状腺癌の早期発見 が三重複癌の切除率向上のための大きな課題となろ 5 .

ちなみに,三重複癌臨床例についての1969年までの 切除率（8 例中 3 例，38\%）と，1970年〜1979年まで の切除率（33例中12例，36\%) の間に統計学的有意差 
はなく切除率の向上はみられていない。

自験例は, 子宮, 胃, 結腸, と発生頻度の高い缄器 の組合わせによる異時性三重複癌症例であり，また比 較的発見頻度の高い癌の組合わせであったために治痹 切除を行ならことができたものと思われるが，異時性 重襩癌は第一癌の術後経過のなかで, 治虑切除可能な 時期に発見，診断する努力が必要であり，癌患者の術 後観察に際しては適切な検査と，慎重な診断がより一 層必要であることを強調したい，

多重癌の成因については，これまで種々の報告がみ られるが, Warthin"27は“Cancer family”について癌に 対する susceptibilityを榆討 し, familiar susceptibility があると報告し，Warren と Gates は重複癌 発生数の期待値より実数値の方が多い事を指摘し，こ れは遗伝，体質によって説明されるかもしれないと述 ぺている. 本邦です増淵28)は子宮内膜癌を含む重複癌 においては遺层的素因があると述べている。

また Hanlon ${ }^{29)}$, Caldwell ${ }^{300}$ ，は多重複癌発生と老龄 化の関係について報告し, LYnch ${ }^{31)}$ は，第一癌と第二癌 の間の癌䍜患率は $3 \% /$ year survival で上昇し，第二 癌と第三癌の間は $6.9 \% /$ year survial で上㫒すると報 告している。Gati ${ }^{32}$ は原発性免度不全の患者は健常人 より約 $10^{4}$ 倍も悪性腫瘍䍜患率が高いと述べているが, Penn ${ }^{33}$ /は抗癌剂使用後に悪性腫瘍を発生した症例を 135例報告しこれら抗癌剤自体に免疫抑制作用がある ために，癌に対する細胞性免废の低下や，Oncogenic virusの増殖を促進するためであろらと推論し， Schmähl ${ }^{34)}$ はアルキル化剂は免疫抑制剤として作用す るよりは, むしろCarcinogenとして生理化学的作用 をむつと報告している。しかし Caldwell ${ }^{30}$ は化学療法 は数種の抗癌剤の組合わせゃ Radiationを併用する ことが多いので特定の Agent に帰するのは困難であ るとしている.

放射線の影響については，浜田ら ${ }^{351}$ は被爆者の悪性 腫瘍剖検例579例中に 20 症例 (3.5\%) の重複癌症例を 認め, 発生頻度的には重複癌についての諸家の報告と 大差なかったが $2 \mathrm{~km}$ 以内被爆者群では最も高率で あったと報告している。一方広島, 長崎での ABCCの 調查から Steer ${ }^{96)}$ は，胃癌，肺癌，白血病および甲状腺 癌に関連した重複癌について被爆との関係を調へ，と くに被爆との関連は見出されなかったと報告してい る.しかし藤田 ${ }^{211}$ は, 三重複癌の $28.6 \%$ に放射線治療の 既往があったと報告しており，今回の集計です，三重 複癌臨床例44例中11例（25\%）が第一癌もしくは第二

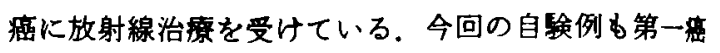
の子宮頝癌の術後放射線療法が行なわれ，11年後にS 状結腸癌が見出されている.Cabrea ${ }^{37}$ (64例の肛門密 のうち，11例が肛門生殖器系の重複癌で，そのうち異 時性の6例中 5 例が放射線治㞠をらけており，放射線に よる重複癌の発生, もしくはその促進の可能性を否定 できないと結論づけている、放射線治療が広く行なわ れるよらになっている現在, 照射部位上新たな癌の発 生部位との関連について詳しく調へられる必要がある と思われる。

内分泌と重複癌の関係については Schoenberg ${ }^{33 !}$, 増濎25)らが乳腺や女性生殖器系の重複源に性ホルモン が関与している可能性を報告し, 㼨器特異性について は Mider ${ }^{39}$ が乳腺, 大腸癌の患者に重複癌の頻度が高 いと述べている.

以上の如く，重複癌の成因に関しては種々の報告が みられるか，近年の癌治療の動向との関連において， 術後長期の癌化学療法ならびに放射線療法上重複癌発 生との因果関保はとくに重要な課題と考えられ，今後 明らかにされることが望ましいと考える。

（本稿の自呀例については，第43回日本臨床外科医学会に 扣いて報告した。）

\section{文 嗝}

1) Warren, S. and Gates, O.: Multiple primary malignant tumors. Am. J. Cancer, 16: 1358 -1414, 1932.

2）赤崎兼義，若狭治毅，石館卓三：原発性重複癌につ いて，日本臨床，19：1543-1551，1961.

3) Moertel, C.G., Docperty, M.B. and Baggenstoss, A.H. : Multiple primary malignant neoplasms. Cancer, $14: 221-231,1961$.

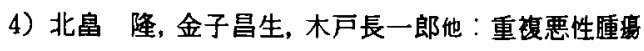
の発見頻度に関して, 癌の臨床， $6: 337-345$, 1960.

5）熊谷廣一，田村和民，坂本要一他：三重䙓癌、日本 臨床, $34: 164-172,1976$.

6）中村恭二，相沢 幹：組合わせよりみた重复癌の 倹討, 癌の臨床, $18 ： 662-666,1972$.

7) 朝合元晴：䁍器の異なる三重複癌の 2 例。日外会 誌, $66: 382,1965$.

8）飯田孔陽, 梅垣样一郎, 御剭一他：国立ガンセン ターに於ける重複癌の検討, 日癌治会誌, $5: 318$, 1970.

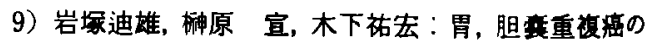
1 例，外科診療， $9 ： 538-542 ， 1967$. 
10）平田弘昭，伊藤慈秀，妹尾蔽：原発性重複癌につ い, Medical Postgraduates, $13: 50-60,1975$.

11）大森高明, 大嶋正人, 谷卦龍夫他：三重複悪性庫湯 の病理解剖例における統計学的検討と 1 剖検例, 癌の臨床, $24: 339-347,1978$.

12）馬場謙介，下里幸雄，渡辺漸他：重複瘦の統計と その問題点, 癌の臨床， $17: 424-436 ， 1971$.

13）坂下 勲, 当間恵三：重裉癌の 1 症例, 日外会誌, $69: 507,1968$.

14）佐藤良蝪, 松岡秀樹：重複癌の 1 つとて発生し た Hürthle cell carcinoma の 1 例, 耳鼻科臨床, $62: 572-576,1970$.

15）天羽達郎, 鈴木博孝, 榊原 宣他：食道胃結腸にわ たる同時性四重复癌の 1 治験例，外科診寮，13： 1021-1025, 1971.

16）三品寿雄，真鍋邦彦、未川元樹：三重複癌の 1 例, 北海道外科医学会雑誌, $17: 282,1972$.

17）谷口遙：三重複癌の 1 手術, 日外会誌, 77 : 1454, 1976.

18）神前五郎：追加発言，日癌治会誌，10：316, 1975 .

19）占部康雄, 田中淳太郎，渡辺節生他：異時性異所性 三重複癌の 1 例, 日内会誌，65：977，1976.

20）松原 毅, 沢田和郎, 刀禰健二他：脳腫瘍を伴5多 発性原発性悪性腫榎の1例，癌の臨床，22： $478-481$.

21）藤田博正, 清水公一, 沢野芳郎他：原発性三重裉癌 の手術例，日臨外会誌，38：840-852，1977.

22）鈴木定雄, 土屋敦雄, 斉藤 徹：重複癌の術後長期 経過をへて発生した下腸間膜動脈閉塞症の 1 治験 例, 臨床外科, $31: 1489-1493,1976$.

23）巟川 真, 松岡富雄, 皆川憲弘他：三重裉癌の 1 例，秋田農村医会誌，26：55, 1979.

24）小田原良治, 野村秀洋, 川路高衛他：胃と他荿器重 複癌の 9 症例, 外科診療, $20: 839-844 ， 1978$.

25）佐本敏彦,鶴 正婎, 柴田龍郎他：三重複癌の 1 治 倹例, 防徫徫生, $26 ： 235-241 ， 1979$.

26）豊永文雄, 永井 项, 横山雅好他：三重被癌に肺過
誤隀を合併した 1 症例, 虎の臨床，26：203-206, 1980.

27) Warthin, A.S.: The further study of a cancer family. J. Cancer Research, 9: 279-281, 1975.

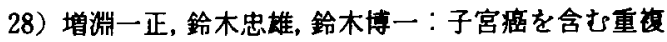
浩について, 癌の臨床, $16: 982-987,1970$.

29) Hanlon, F.R.: Multiple primary carcinomas, Am. J. Cancer, $15:$ 2001-2011, 1931.

30) Caldwell, G.G.: Second primary malignancies as a delayed result of therapy. Cancer, $40: 1952$ $-1953,1977$.

31) LYnch, H.T., Harris, R.E. and Lynch, P.M.: Role of heredity in multiple primary cancer, Cancer. $40: 1846-1854,1977$.

32) Gati, R.A. and Good, R.A.: Ocurrence of malignacy in immunodeficiency diseases. Cancer, $28: 89-98,1971$.

33) Penn, I: Chemical immunosupression and human cancer. Cancer, $34: 1474-1480,1974$.

34) Schmahl, D.: Carcinogenic action of antican. cer drugs with special reference to immunosuppression. Cancer, 40 : 1927-1929, 1977.

35）浜田忠雄，石田 定：被爆者にみられた重複癌に つい, 長崎医学会雑誌, $47: 311-318,1972$.

36）Steer, A. : 広島, 長崎, 固定人口集団における重 复癌々放射線との関俰, 日本病理学会誌, $59: 105$, 1971.

37) Cabrea, A., Tsukada, Y., Pickres, J.W., et al. : Development of lower genital carcinomas in patients with anal carcinoma. Cancer, 19: 470 $-480,1966$.

38) Shoenberg, B.S., Greenberg, R.A., Eisenberg, H., et al. : Occurrence of certain multiple primary cancers in female. J. Nat. Cancer. Inst., $43: 15$ $-32,1969$.

39) Mider, G.B., Schilling J.A. and Donovan, J.C. : Multiple cancer. Cancer, 5 : 1104-1109, 1952. 